\title{
Evaluation of the Techno-Economic Benefits of Shifting Air Conditioning Loads from Evening and Day Peaks to Off Peak Hours A Case Study
}

\author{
T.G. R. Lalitha, W.D.A.S. Wijayapala and C.N. Dalugoda
}

\begin{abstract}
With the development of industries and changes in living standards of the society, demand for electricity is rapidly increasing. In order to maintain the demand supply balance and to provide uninterrupted supply, utilities have to meet electricity demand in the most economical way. Building new power plants is not always the most economical solution. The trend now, is towards reducing and controlling the demand through Demand Side Management (DSM) techniques which lead to almost always economical and environment-friendly solutions.

In this paper, Heating, Ventilation and Air Conditioning (HVAC) system of Cinnamon Lakeside Hotel is analysed to identify the potential DSM options that can be implemented. Thermal Energy Storage (TES) was selected as the DSM option to store cooling load during off-peak hours of the day where electricity is fairly cheap and use it during peak and day hours when the electricity is expensive. Technical viability and potential saving that can be achieved through TES in hotel sector of Sri Lanka is further analysed.
\end{abstract}

Key words: Thermal energy storage, Coefficient of performance, Electricity demand

\section{Introduction}

Thermal comfort is a main factor in modern day building designs. Air conditioners are generally used to provide thermal comfort inside buildings. Use of air conditioning is increasing around the world, contributing to a substantial increase of demand for electricity.

HVAC systems in industrial, commercial and residential buildings are the largest single contributor to electricity demand, especially during daytime [2].

Sri Lanka's daily electricity demand curve shows a predominant evening peak which is served by expensive gas turbines operated on diesel oil [5]. Therefore, all efforts must be taken to shift loads from the peak demand period and flatten the demand curve for better utilization of the capital investments.

During recent years, considerable research has been done aimed at the development of technologies that can offer reduction in energy consumption, peak electrical demand and energy costs, without affecting the level of thermal comfort. In this context, cold Thermal Energy Storage (TES) systems can play an important role as they provide great potential for improved energy efficiency, conservation and reduction in peak electrical load.
The demand for electricity in Sri Lanka is continuously increasing, growing at an average rate of $5.0 \%$ per year (20 Year growth average) [5]. Additional power plants must be constructed to satisfy this demand. It is estimated that Sri Lanka must invest around US\$ 8.58 billion over the next twenty years [2] to finance an expansion program for an additional $8,363 \mathrm{MW}$ of generating capacity to cope with this predicted demand. Therefore, shifting air conditioning load to off peak hours using storage methods will reduce the investment on costly generation plants.

This paper presents techno-economic benefits of shifting air conditioning load from peak to off peak hours by using cold TES through a case study for a large-scale hotel.

Eng. T.G.R. Lalitha, BSc Eng (Hons) (Moratuwa) MSc.(Moratuwa), AMIE(SL), Electrical Engineer, Renewable Energy Projects, Ceylon Electricity Board. Email:rajith.sac@gmail.com

Eng. (Prof.)W.D.A.S. Wijayapala, B.Sc Eng (Hons) (Moratuwa), MEng(Moratuwa), Int.PEng(SL), CEng, FIE(SL), Associate Professor, Department of Electrical Engineering, University of Moratuwa. Email:anuraw@uom.lk

Eng. C.N. Dalugoda, CEng MIE, MCIBSE, FASHRAE, GCGI, MConsE(SL), Chartered Mechanical Engineer. Email:chandana_cnd@sltnet.lk 
Methodology:

- Identification of the HVAC load pattern and energy consumption of the HVAC system.

- Identification of the optimum thermal energy storage required and cost-effective technology to be used for the storage.

- Evaluation of the economic benefits to the industry and to the utility.

\section{Identification of the HVAC Load Pattern and Energy Consumption of the HVAC System.}

HVAC system consumes around $60 \%$ of its total electricity consumption in a large hotel [5]. Further analysis shows that $30 \%$ to $40 \%$ of electricity consumption of the HVAC system is from the central plant which consists of chillers and cooling towers. Break down of electrical energy use in a typical hotel building is given in Figure 1 [4].

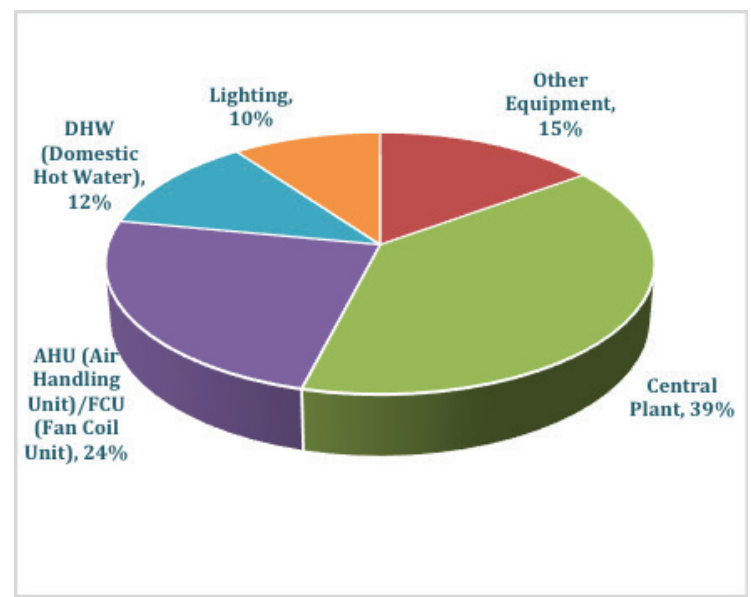

Figure 1 - Breakdown of Electricity

Consumption of a Large Hotel

Existing HVAC system of Cinnamon Lakeside hotel consists of one 455 TR Single Screw DAIKIN Chiller and two 300 TR cooling towers and several pumps and fan coil units.

Two 300 TR cooling towers are operating at their full capacity throughout the day and each cooling tower is rated $7.5 \mathrm{~kW}$ at full load.

\subsection{Average Load Profile of the Chiller Plant of Cinnamon Lakeside Hotel}

Figure 2 shows the average load profile of the chiller at Cinnamon Lakeside Hotel. The average load profile of the chiller shows that there is a possibility of shifting cooling load to off peak hours as there is a low demand in the off-peak hours compared to the peak and day hours. The utility defines "Day" period as from 05.30 hours to 18.30 hours, "Peak" period as from 18.30 hours to 22.30 hours and "Off-Peak" period as from 22.30 hours to 05.30 hours for Time of Use (TOU) tariff.

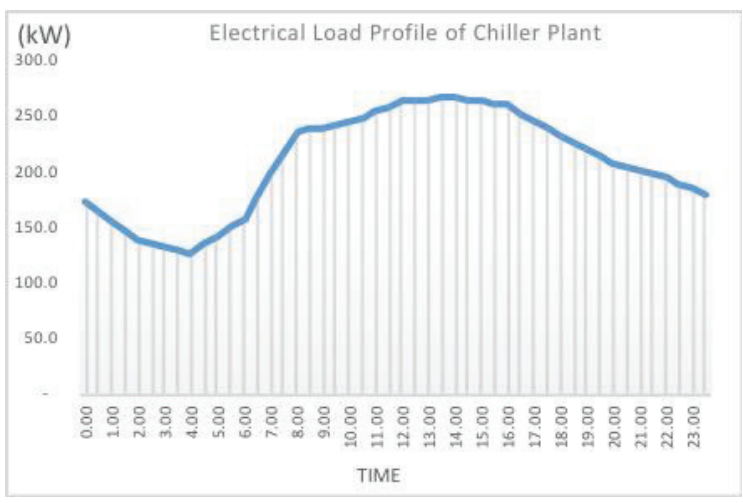

Figure 2 - Average Electrical Load Profile of Chiller

\subsection{Data Analysis}

Breakdown of the average energy consumption per day of chiller and cooling towers in TOU time slots are shown in Figure 3.

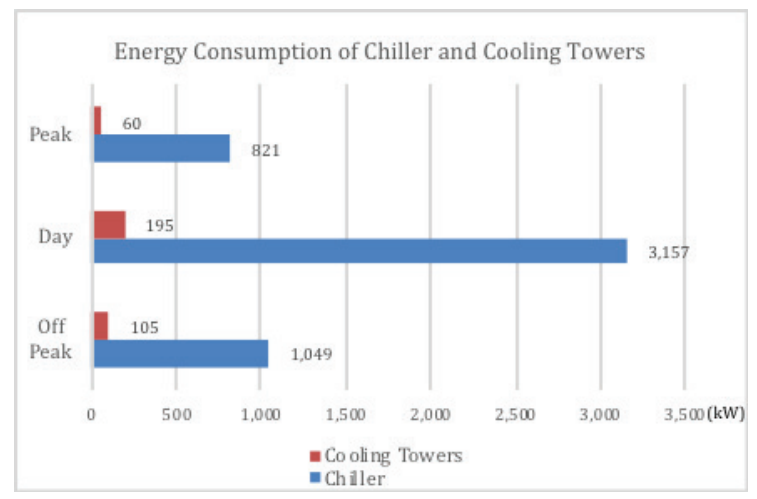

Figure 3 - Average Energy Consumption per Day of Chiller and Cooling Towers

A Ton of Refrigeration (TR) is a unit of power used to describe the heat extraction capacity of refrigeration and air conditioning equipment. It is defined as the rate of heat transfer that results in the melting of 1 short ton $(2,000 \mathrm{lb}$; $907 \mathrm{~kg}$ ) of pure ice at $0{ }^{\circ} \mathrm{C}$ in 24 hours. Equations 1 and 2 show the relationships among parameters $\mathrm{kW}, \mathrm{CIP}, \mathrm{kWe}$ and TR.

$\mathrm{kW}_{\mathrm{R}}=\mathrm{COP} \times \mathrm{kWe}$

$\mathrm{TR}=\mathrm{kW} / 3.51$

where:

$\mathrm{kW}=$ kilowatt (electrical)

$\mathrm{kW}_{\mathrm{R}}=$ kilowatt (cooling) 
$\mathrm{COP}=$ Coefficient of Performance

Table 1 - Breakdown of Load Profile

\begin{tabular}{|c|c|c|c|c|}
\hline & $\begin{array}{c}\text { Off Peak } \\
\mathbf{( 2 2 . 3 0 -} \\
\mathbf{0 5 . 3 0 )}\end{array}$ & $\begin{array}{c}\text { Day } \\
\mathbf{( 0 5 . 3 0 -} \\
\mathbf{1 8 . 3 0 )}\end{array}$ & $\begin{array}{c}\text { Peak } \\
\mathbf{( 1 8 . 3 0 -}\end{array}$ & Total \\
\hline Energy (kWeh) & $1,048.9$ & $3,156.9$ & 821.3 & $5,027.1$ \\
\hline $\begin{array}{c}\text { Cooling Load } \\
\text { (kWh) }\end{array}$ & $5,926.2$ & $17,836.7$ & $4,640.1$ & $28,403.0$ \\
\hline $\begin{array}{c}\text { Cooling Load } \\
\text { (TRh) }\end{array}$ & $1,688.4$ & $5,081.7$ & $1,322.0$ & $8,092.0$ \\
\hline
\end{tabular}

2.3. Methods of Air Conditioning Load Shifting

A Chilled Water Storage System (CWS) and an Ice Storage System (IS) are selected as possible load shifting methods for further analysis.

CWS is a TES using sensible heat of water to store energy during off-peak hours. Vertical cylinder tanks are the most common shape of tanks used for CWS [4] and they can be located above ground, partially buried or completely buried depending on the location. Tank capacity depends on the amount of cooling load to be stored and temperature difference between stored chilled water and return water. Existing chillers can be used in this method.

Ice storage is a proven technology that reduces chiller size and shifts compressor load, condenser fan and pump loads from peak periods to off-peak periods, where electrical energy is less expensive.

The latent heat of fusion of water (phase change of water to ice or ice to water) is used in this process to store cooling load. Water is used as a phase change storage medium in order to take advantage of its higher storage capacity. In this method it is required to use glycol chillers and heat exchangers.

Following parameters are taken into account when calculating the energy consumption of each method.

Heat exchanger energy loss $01 \%[3]$

Ice Storage energy loss

Chilled Water Storage energy loss 10\% [1]

\section{Identification of the optimum thermal energy storage required}

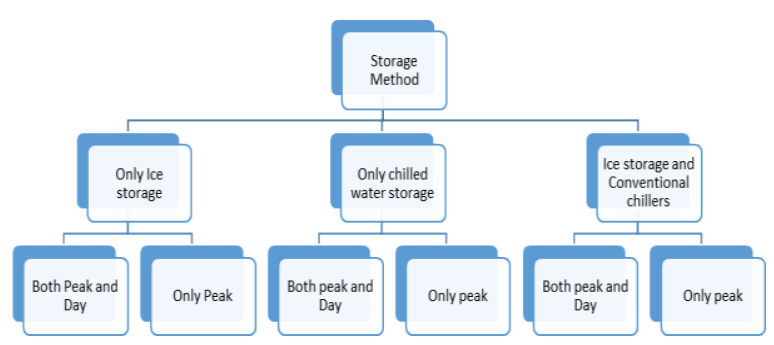

Figure 4 - Methods of Load Shifting

3.1. Using only Glycol Chillers and Ice Storage Systems

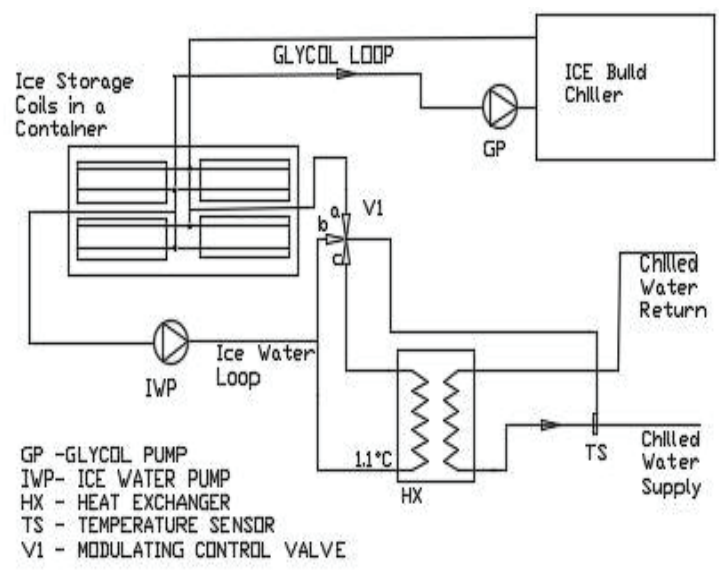

Figure 5 - Ice Storage System with Glycol Chillers Only [3]

\subsubsection{Case 01: Shifting both peak and day cooling loads}

Only Glycol chillers are used and total peak and day cooling load of 6,403.7 TRh should be stored during off-peak hours.

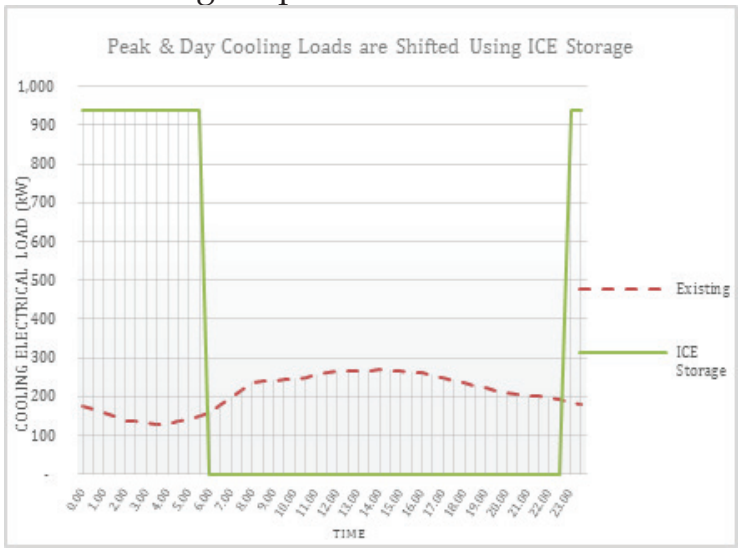

Figure 6 - Load Profile of Chiller Shifting Peak and Day using Ice Storage 
A Glycol chiller of 1,176.80 TR (936.6 kWe) is required for the proposed case and total electrical energy consumption of the chiller is 6,556.5 kWhe.

\subsubsection{Case 02: Shifting peak cooling load only}

Only Glycol chillers are used and peak cooling load of 1,322.0 TRh should be stored during off-peak hours.

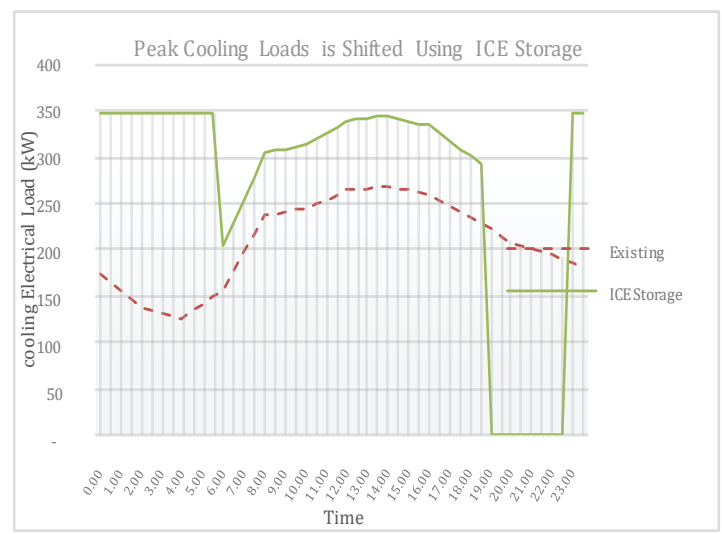

Figure 7 - Load Profile of Chiller Shifting Only Peak using Ice Storage

A Glycol chiller of 436.26 TR (347.2 kWe) is required for the proposed case and total electrical energy consumption of the chiller is 6,515.6 kWhe.

\subsection{Using Chilled Water Storage Systems}

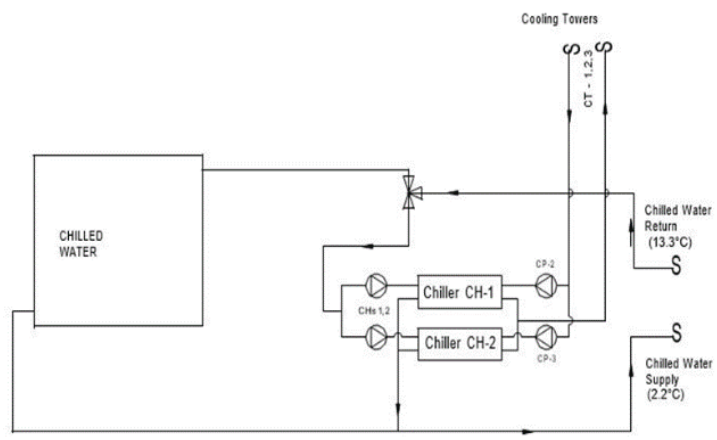

CHS. CHILED WATER PUMP

CH.1, 2. CONVENTONAL CHILU
CP. CONOENSER WATEP PUUP

Figure 8 - Chilled Water Storage System

3.2.1. Case 03: Shifting both peak and day cooling loads

Only conventional chillers are used for shifting both the peak and day cooling loads to offpeak hours using chilled water storage system.

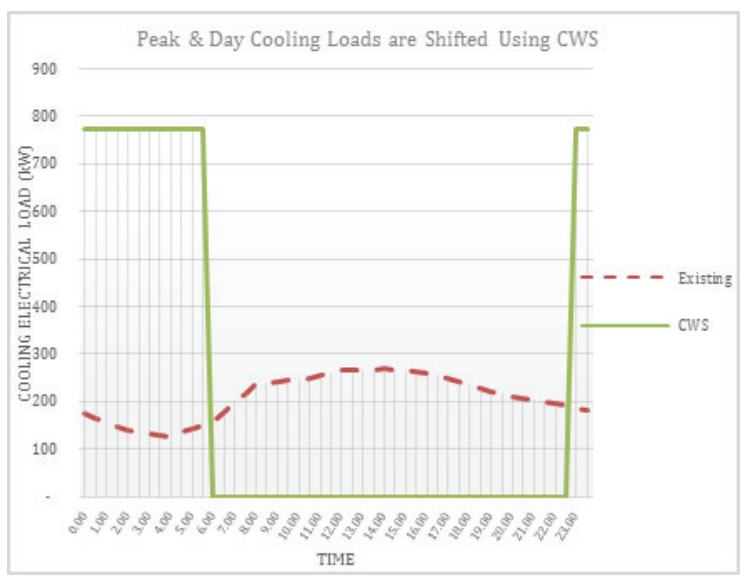

Figure 9 - Load Profile of Chiller Shifting Peak and Day using Chilled Water Storage

A conventional chiller of 1,247.49 TR (774.99 $\mathrm{kWe}$ ), which is higher than the existing chiller capacity, is required. Total electrical energy consumption of the chiller is 5,424.9 kWhe.

\subsubsection{Case 04: Shifting peak cooling load} only

Total peak cooling load of 1,322.0 TRh should be stored during off-peak hours using conventional chillers.

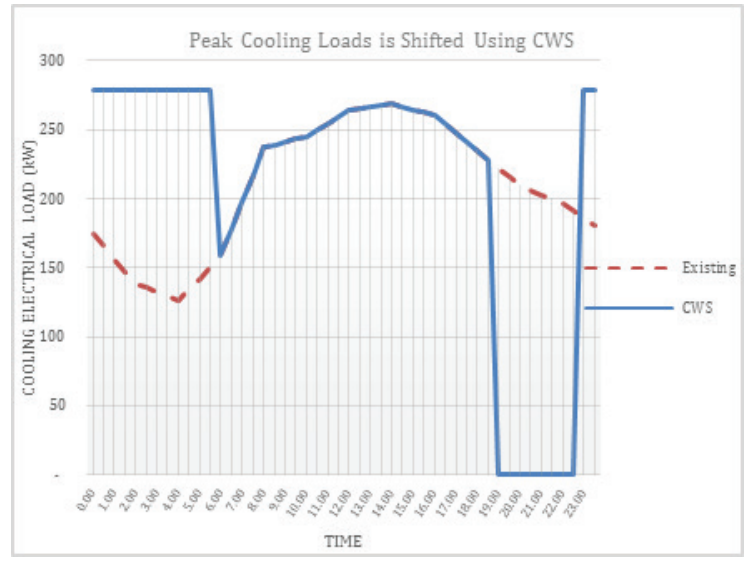

Figure 10 - Load Profile of Chiller Shifting Only Peak using Chilled Water Storage

A conventional chiller of 448.94 TR (278.9 $\mathrm{kWe}$ ), having a capacity lower than that of the existing chiller, is required. Hence, no additional chiller is needed. Total electrical energy consumption of the chiller is 5,109.2 kWhe. 
3.3. Shifting cooling load using ice storage system and conventional chillers

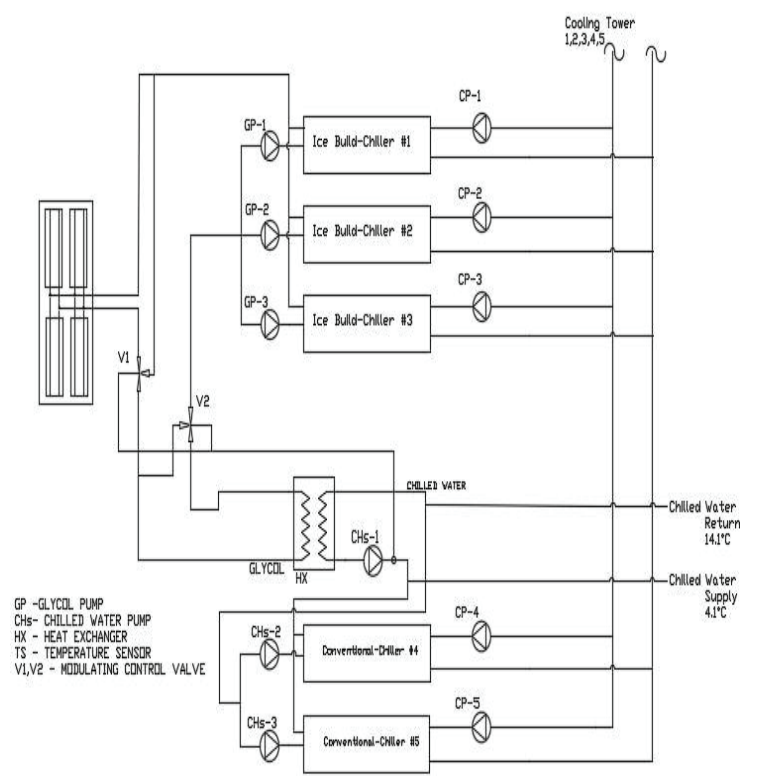

Figure 11 - Ice Storage System with Glycol Chillers and Conventional Chillers

\subsubsection{Case 05: Shifting both peak and day cooling loads}

Glycol chiller is used only for ice making purposes and conventional chiller is used to meet the cooling load during off-peak hours.

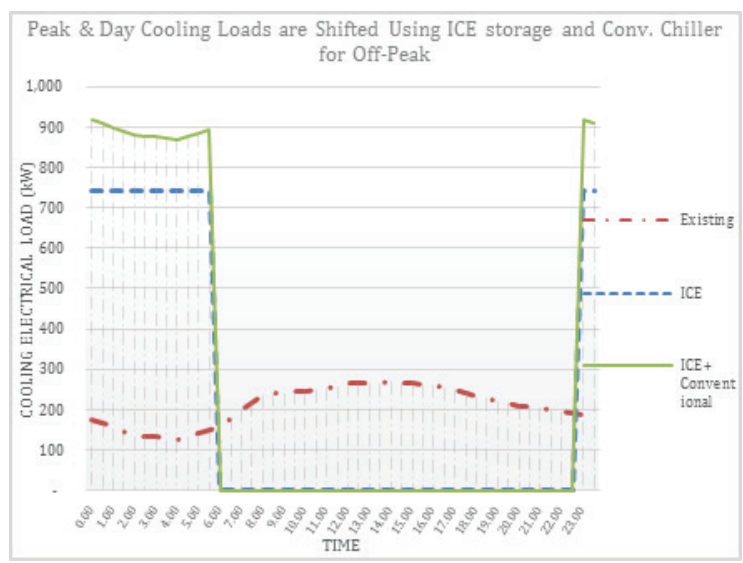

Figure 12 - Load Profile of Chiller Shifting Peak and Day using Ice Storage and Conventional Chiller

A Glycol chiller of 923.96 TR (735.4 kWe) and a conventional chiller of 241.20 TR (149.9 kWe) are required for the proposed case. Total electrical energy consumption of the chillers is 6,248.1 kWhe.

\subsubsection{Case 06: Shifting peak cooling load only}

Glycol chiller is only used for ice making and conventional chiller is used to meet the cooling load during day and off-peak hours.

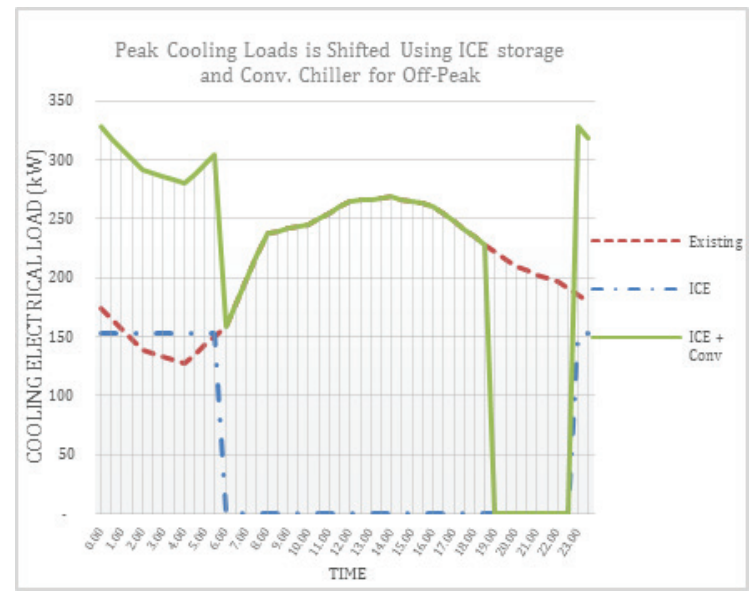

Figure 13 - Load Profile of Chiller Shifting Only Peak using Ice Storage and Conventional Chiller

A Glycol chiller of 190.74 TR (151.8 kWe) and a conventional chiller of 390.90 TR (242.8 kWe) are required for the proposed case. Total electrical energy consumption of the chillers is 5,279.2 kWhe.

\subsection{Storage Calculation}

Storage required to shift peak and day cooling load to off-peak is 6,403.7 TRh and to shift peak cooling load to off-peak is 1,322.0 TRh.

Equation 3 is used to calculate the required storage capacity for chilled water and Equation 4 is used to calculate the required storage capacity for ice storage.

$\mathrm{V}=\frac{\mathrm{X} * 12,000 \mathrm{Btu} / \text { Tonhours }}{\mathrm{L} * \mathrm{SG} * \mathrm{eff} * 1000} * 0.454 \mathrm{~kg} / \mathrm{lb}$

where;

$\mathrm{V}=$ TES tank volume, $\mathrm{m}^{3}$

$\mathrm{X}=$ amount of thermal capacity required, ton-h

$\mathrm{L}=$ latent heat of fusion of ice, $\mathrm{Btu} / \mathrm{lb}$

$\mathrm{SG}=$ specific gravity, $\mathrm{kg} / \mathrm{m}^{3}$

eff = storage efficiency, typically 0.99

$V=\frac{X * 12,000 \mathrm{Btu} / \mathrm{Tonhours}}{C p * \Delta T * S G * \text { f f } * 1000} * 0.454 \mathrm{~kg} / \mathrm{lb}$

where;

$\mathrm{V}=$ TES tank volume, $\mathrm{m}^{3}$

$\mathrm{X}=$ amount of thermal capacity required, ton-h

$\Delta \mathrm{T}=$ temperature difference, ${ }^{\circ} \mathrm{C}$

$\mathrm{CP}=$ specific heat of water, $\mathrm{Btu} / \mathrm{lb}^{\circ} \mathrm{C}$ 
$\mathrm{SG}=$ specific gravity, $\mathrm{kg} / \mathrm{m}^{3}$

eff $=$ storage efficiency, typically 0.90

\subsection{Summary}

Table 2 - Summary of Six Cases

\begin{tabular}{|c|c|c|c|c|}
\hline & \multicolumn{3}{|c|}{ Energy Consumption (kWhe) } & \multirow{2}{*}{$\begin{array}{c}\text { Storage } \\
\text { Volume } \\
\left(\mathrm{m}^{3}\right)\end{array}$} \\
\hline & Chillers & $\begin{array}{l}\text { Cooling } \\
\text { Towers }\end{array}$ & Total & \\
\hline Case 01 & $6,556.5$ & 262.5 & $6,819.0$ & 285.57 \\
\hline Case 02 & 6 & 300.0 & $6,815.6$ & 58.95 \\
\hline Case 03 & $5,424.9$ & 262.5 & $5,687.4$ & 832.48 \\
\hline Case 04 & $5,109.2$ & 300.0 & $5,409.2$ & 171.86 \\
\hline Case 05 & $6,248.1$ & 262.5 & $6,510.6$ & 285.57 \\
\hline Case 06 & $5,279.2$ & 300.0 & $5,579.2$ & 58.95 \\
\hline
\end{tabular}

Table 2 summarises the six cases for comparison. Case 02 and Case 06 require lower storage volumes compared to other cases and Case 04 consumes the lowest energy compared to others.

\section{Financial Analysis}

\subsection{Operating Cost}

Energy consumption of chiller and cooling towers are considered when calculating the operating cost of the existing system as they are the main components to be replaced when implementing the TES. Table 3 below shows the energy usage as well as the applicable electricity costs during the "Off Peak", "Day" and "Peak" durations.

\section{Table 3 - Per day Operation Cost of the} Chiller

\begin{tabular}{|r|r|r|r|}
\hline \multicolumn{1}{|c|}{ TOU } & $\begin{array}{c}\text { Energy } \\
\text { (kWh) }\end{array}$ & $\begin{array}{c}\text { Tariff } \\
\text { (LKR/kWh) }\end{array}$ & Cost (LKR) \\
\hline Off peak & $1,048.9$ & 8.80 & $9,230.22$ \\
\hline Day & $3,156.9$ & 13.70 & $43,250.00$ \\
\hline Peak & 821.3 & 22.50 & $18,478.45$ \\
\hline Total & $5,027.1$ & & $70,958.66$ \\
\hline & & & \\
\hline
\end{tabular}

Accordingly, the Table 4 shows the cooling tower's Operating costs for a day.

Table 4 - Per Day Operation Cost of the Cooling Tower

\begin{tabular}{|r|r|r|r|}
\hline \multicolumn{1}{|c|}{ TOU } & $\begin{array}{c}\text { Energy } \\
\text { (kWh) }\end{array}$ & $\begin{array}{c}\text { Tariff } \\
\text { (LKR/kWh) }\end{array}$ & Cost (LKR) \\
\hline Off peak & 105 & 8.8 & 924.00 \\
\hline Day & 195 & 13.7 & $2,671.50$ \\
\hline Peak & 60 & 22.5 & $1,350.00$ \\
\hline Total & 360 & & $4,945.50$ \\
\hline
\end{tabular}

Total Chiller and Cooling Tower power consumption of the existing system is 5,387.1 kWhe and per day operation cost is LKR 75,904.16.

\subsection{Operating Cost of Proposed cases}

Case 01

$\begin{array}{ll}\text { Storage Capacity } & =6,403.7 \mathrm{TRh} \\ \text { Glycol Chiller } & =1,176.8 \mathrm{TR} \\ \text { Cooling Towers } & =5 \text { Nos. of } 300 \mathrm{TR} \\ \text { Operating cost } & =\text { LKR } 60,007.00 / \text { day } \\ \text { Total savings per year } & =\text { LKR } 5,802,448.00\end{array}$

Case 02

$\begin{array}{ll}\text { Storage Capacity } & =1,322 \mathrm{TRh} \\ \text { Glycol Chiller } & =436.3 \mathrm{TR} \\ \text { Cooling Towers } & =2 \text { Nos. of } 300 \mathrm{TR} \\ \text { Operating cost } & =\text { LKR } 80,949.00 / \text { day }\end{array}$

Operating cost of the proposed system is higher than the existing system. Therefore no saving can be expected from this case.

\section{Case 03}

$\begin{array}{ll}\text { Storage Capacity } & =6,403.7 \mathrm{TRh} \\ \text { Glycol Chiller } & =1,247.49 \mathrm{TR} \\ \text { Cooling Towers } & =5 \text { Nos. of } 300 \mathrm{TR} \\ \text { Operating cost } & =\text { LKR } 50,049.00 / \text { day } \\ & \\ \text { Total savings per year } & =\text { LKR } 9,437,068.00\end{array}$

\section{Case 04}

$\begin{array}{ll}\text { Storage Capacity } & =1,322 \mathrm{TRh} \\ \text { Glycol Chiller } & =448.9 \mathrm{TR} \\ \text { Cooling Towers } & =2 \text { Nos. of } 300 \mathrm{TR} \\ \text { Operating cost } & =\text { LKR } 65,375.00 / \text { day } \\ & \\ \text { Total savings per year } & =\text { LKR } 4,335,692.00\end{array}$

Case 05

$$
\begin{array}{ll}
\text { Storage Capacity } & =6,403.7 \mathrm{TRh} \\
\text { Glycol Chiller } & =924 \mathrm{TR} \\
\text { Conventional Chiller } & =241.2 \mathrm{TR} \\
\text { Cooling Towers } & =5 \text { Nos. of } 300 \mathrm{TR} \\
\text { Operating cost } & =\text { LKR } 57,293.00 / \text { day } \\
\text { Total savings per year } & =\text { LKR } 6,792,912.00
\end{array}
$$

Case 06

$\begin{array}{ll}\text { Storage Capacity } & =1,322 \mathrm{TRh} \\ \text { Glycol Chiller } & =190.7 \mathrm{TR}\end{array}$


Conventional Chiller $=390.9 \mathrm{TR}$

Cooling Towers $\quad=2$ Nos. of $300 \mathrm{TR}$

Operating cost = LKR 65,521.00/day

Total savings per year $=$ LKR 3,789,829.00

\subsection{Investment Cost}

The main investment is the installation cost of the equipment. Based on market prices prevailed in 2017. Costs used in this study for the financial analysis are shown in Table 5.

Table 5 - Cost of HVAC Equipment (Year 2017)

\begin{tabular}{|l|r|l|r|}
\hline Item & \multicolumn{2}{|c|}{ Capacity } & Price (LKR) \\
\hline Glycol Chiller & $\mathbf{2 0 0}$ & TR & $\mathbf{1 3 , 5 0 0 , 0 0 0 . 0 0}$ \\
\hline $\begin{array}{l}\text { Glycol Chiller } \\
\text { Conventional } \\
\text { Chiller }\end{array}$ & $\mathbf{3 0 0}$ & TR & $\mathbf{2 2 , 0 0 0 , 0 0 0 . 0 0}$ \\
\hline $\begin{array}{l}\text { Conventional } \\
\text { Chiller }\end{array}$ & $\mathbf{1 5 0}$ & TR & $\mathbf{7}, \mathbf{5 0 0 , 0 0 0 . 0 0}$ \\
\hline $\begin{array}{l}\text { Conventional } \\
\text { Chiller }\end{array}$ & $\mathbf{2 0 0}$ & TR & $\mathbf{1 0 , 5 0 0 , 0 0 0 . 0 0}$ \\
\hline $\begin{array}{l}\text { Conventional } \\
\text { Chiller }\end{array}$ & $\mathbf{3 0 0}$ & TR & $\mathbf{1 3 , 0 0 0 , 0 0 0 . 0 0}$ \\
\hline $\begin{array}{l}\text { Conventional } \\
\text { Chiller }\end{array}$ & $\mathbf{4 5 0}$ & TR & $\mathbf{2 6 , 0 0 0 , 0 0 0 . 0 0}$ \\
\hline Ice Storage & $\mathbf{2 5 0}$ & TRh & $\mathbf{2 , 2 2 5 , 0 0 0 . 0 0}$ \\
\hline Chilled Water S & $\mathbf{1}$ & $\mathbf{m}$ & $\mathbf{5 5 , 0 0 0 . 0 0}$ \\
\hline Heat Exchanger & $\mathbf{2 0 0}$ & $\mathbf{R T}$ & $\mathbf{2 , 1 5 0 , 0 0 0 . 0 0}$ \\
\hline Heat Exchanger & $\mathbf{4 2 0}$ & $\mathbf{R T}$ & $\mathbf{3 , 6 3 5 , 0 0 0 . 0 0}$ \\
\hline Cooling Tower & $\mathbf{3 5 0}$ & TR & $\mathbf{2 , 2 0 0 , 0 0 0 . 0 0}$ \\
\hline Pumps & $\mathbf{1}$ & & $\mathbf{5 0 0 , 0 0 0 . 0 0}$ \\
\hline Pipe work & $\mathbf{1}$ & $\mathbf{m}$ & $\mathbf{1 0 , 0 0 0 . 0 0}$ \\
\hline Insulation & $\mathbf{1}$ & $\mathbf{m}$ & $\mathbf{3} \mathbf{6 0 0 . 0 0}$ \\
\hline
\end{tabular}

\subsection{Benefits to the Industry}

The customers will be benefited through shifting their peak time energy usage to offpeak period due to the TOU tariff offered by the CEB.

To evaluate the viability of the investment, simple payback period for the investment and project IRR (Internal Rate of Return) was calculated.

For calculating the IRR following parameters were considered.

- Project life time

$=20$ years

- Resale value after 20 years $=40 \%$ (for chillers only)

- Debt: Equity ratio

$=70: 30$

- Loan period

$=07$ years

- Loan interest

$=16 \%$

Summary of financial analysis done for six cases is shown in Table 7.
Table 6 - Summary of financial analysis

\begin{tabular}{|l|r|r|r|r|}
\hline & $\begin{array}{c}\text { Total } \\
\text { Investment } \\
\text { (MLKR) }\end{array}$ & $\begin{array}{c}\text { Savings } \\
\text { Per Year } \\
\text { (MLKR) }\end{array}$ & $\begin{array}{c}\text { Simple } \\
\text { Pay back }\end{array}$ & \multicolumn{1}{c|}{$\begin{array}{c}\text { Project } \\
\text { IRR }\end{array}$} \\
\hline Case 01 & 173.52 & 5.80 & 29.90 & $(0.21 \%)$ \\
\hline Case 02 & - & $(1.84)$ & - & - \\
\hline Case 03 & 106.46 & 9.44 & 11.28 & $6.78 \%$ \\
\hline Case 04 & 10.53 & 4.34 & 2.43 & $40.76 \%$ \\
\hline Case 05 & 146.48 & 6.79 & 21.56 & $1.52 \%$ \\
\hline Case 06 & 30.70 & 3.79 & 8.10 & $10.78 \%$ \\
\hline
\end{tabular}

\subsection{Utility Benefits}

Benefits to the utility can be calculated using avoided cost method. Data from system control centre of Ceylon Electricity Board (CEB) shows that usually 115MW, GT7_Gas turbine at Kelanitissa power station, 160MW, combined cycle AES Kelanitissa power station and 300MWX3, Lakvijaya coal power station are in the merit order dispatch margin during Peak, Day and Off-peak periods. Therefore, energy reduction in peak period is considered to be reduced from GT 7 and reduction in the day period is considered to be from AES power plant. Energy increase in the off-peak period due to shifted load is considered to be from Lakvijaya coal power station.

The operating costs of these power plants are shown in Table 7.

\section{Table 7 - Unit Cost of Power Plant (2017} prices)

\begin{tabular}{|l|c|}
\hline Power Plant & $\begin{array}{c}\text { Unit Cost } \\
(\text { LKR/kWh) }\end{array}$ \\
\hline GT7 & 47.56 \\
\hline AES & 22.45 \\
\hline Lakvijaya & 7.32 \\
\hline
\end{tabular}

Project IRR was calculated from the utility side for the above six cases expecting investment will be done by the utility.

Table 8 - Calculated Project IRR from Utility side

\begin{tabular}{|c|r|r|r|}
\hline & $\begin{array}{c}\text { Savings Per Year } \\
\text { (LKR) }\end{array}$ & $\begin{array}{c}\text { Simple } \\
\text { Pay back } \\
\text { (years) }\end{array}$ & $\begin{array}{c}\text { Project } \\
\text { IRR }\end{array}$ \\
\hline Case 01 & $26,245,868.00$ & 6.61 & $13.85 \%$ \\
\hline Case 02 & - & - & - \\
\hline Case 03 & $28,444,737.00$ & 3.74 & $26.05 \%$ \\
\hline Case 04 & $11,855,498.00$ & 0.89 & $112.50 \%$ \\
\hline Case 05 & $26,245,868.00$ & 5.58 & $16.86 \%$ \\
\hline Case 06 & $11,401,561.00$ & 2.69 & $36.67 \%$ \\
\hline
\end{tabular}


From Table 8, it can be seen that Cases 3, 4 and 6 are financially viable and Case 4 presents a very attractive option.

The benefits gained from shifting AC load to the utility are not only limited to reducing cost of power generation. Some of the benefits which were not considered into the calculation are:

- Delay in the investment costs on new power plants that will be required if demand is not reduced.

- Delay in the investment on transmission and distribution upgrades.

- Efficiency improvement of the coal power plants during off-peak time through the increased demand and avoiding of deloading the units.

- Increase in the system stability.

\section{Conclusions}

CWS with shifting only the peak cooling load to off-peak hours is the best TES solution for the Cinnamon Lakeside Hotel because no additional chillers are required. Space limitations should also be considered when selecting a TES system. Shifting only peak cooling load to off-peak also requires less storage capacity compared to shifting both peak and day cooling loads.

Simple payback of 2.43 years and project IRR of $40.76 \%$ for case 04 are good financial indicators for a project. These figures will attract investors on TES shifting peak cooling load to off-peak hours using CWS system.

Ice storage systems will increase the temperature difference between return water and chilled water. This will reduce the chilled water flow rate required to meet the cooling load of the building. Reduction of the chilled water flow rate will reduce the pump and fan motor sizes which reduce the energy consumption and investment of the HVAC system. Ice storage system will also reduce the duct and pipe sizes due to high temperature difference achieved between chilled water and return water.

Implementing an ice storage system at the construction stage of a hotel will reduce the investment on HVAC system due to the reduction of equipment sizes, duct work and pipe diameter sizes. This would also reduce the total energy consumption of HVAC system due to reduction of equipment sizes. Implementing the ice storage system at the initial stage of construction could give high project IRR for case 06 which would attract investors.

Shifting only peak cooling load to off-peak hours at the selected hotel will reduce the utility peak demand by $205 \mathrm{~kW}$. If this can be projected to 50 similar capacity buildings, utility can achieve $10 \mathrm{MW}$ peak shavings.

\section{References}

1. ASHRAE Handbook, "HVAC Systems and Equipment, 2012", 2012

2. Eskom Integrated Demand Management, Escom Holdings SOC Ltd, "Heating, Ventilation and Air Conditioning (HVAC) Systems: Energy-Efficient Usage and Technologies", July 2015.

3. EVAPCO, INC, 5151 Allendale Lane, Taneytown, MD 21787, "Thermal Ice Storage, Application and Design Guid", 2007.

4. Kristoper L. Kinney, Eng. Lock Lee, “A Showcase for Energy Efficient Hotels in South Asia".

5. Transmission \& Generation Planning Branch, Transmission Division, Ceylon Electricity Board - Sri Lanka, “Long term generation expansion plan 2018-2037", 2017. 